\title{
Effect of Unionization, Product Market Concentration and Foreign Trade on Inter-Industry Wage Structure
}

\author{
MOHAMMAD IRFAN*
}

\begin{abstract}
Determinants of the inter-industry wage differentials in Pakistan's manufacturing sector are identified in this study. It is argued that only the skill of the production workers cannot explain all the differences in the wages. Results of this study suggest that workers'organization and industrial characteristic such as profitability, capital intensity and product market structure do have a bearing on industrial wage level.
\end{abstract}

Wage structure refers to the wide spectrum of wage rates actually paid to various categories of workers in different firms and industries. The relationships these different rates bear among themselves and the direction and extent of their variation over time reflect the influence of a number of forces on wage determination. Hence a satisfactory answer to any question on wage policy, e.g. the allocation of labour among different industries, requires an identification of these forces.

Wage structure, the analysis of which can be carried out from many angles, is a vast field. The present paper confines the analysis only to a study of inter-industry wage differentials to determine the relative impact of forces like trade unions, monopoly in the product market, foreign trade and quality of the workers on the wage structure.

Inter-industry wage differentials reflect variations in the quality of workers and skill levels and the differences in the structure of product and labour market among industries. One normally should expect the skill of the industrial workers and their wages to be positively related. However, empirical evidence shows that only a part of the wage differentials can be accounted for by the skill factor. The ability of the firms to pay more than the going wage, which is a function of the product market structure, and the degree of unionization are

*The author is a Research Economist at the Pakistan Institute of Development Economics (PIDE). The paper is a part of his $\mathrm{Ph}$. D. thesis successfully completed at the Cornell University, USA. The author is grateful to his thesis adviser, Walter Galenson, and members of the thesis advisory committee, Erik Thorbeck and Ronald G. Ehrenberg, for their guidance. The author also thanks Syed Nawab Haider Naqvi and A.R. Kemal, Director and Senior Research Economist, respectively, at the PIDE, for helping in improving the exposition of the paper. Any errors or omissions are, however, the sole responsibility of the author. 
considered to be the other important variables explaining wage inequalities across different industries for a given skill class.

The effect of the structure of the product market on wage structure has been variously explained in the literature. Large firms tend to pay wage premiums to isolate wages from the pressure of market forces for the planning period and to ensure adequate supply of labour. Firms in concentrated industries may grant higher wages also because of an inelastic demand for their products and, hence, for labour. Higher profitability due to barriers on entry of new firms may result in higher wages either from union pressures or management benevolence. Furthermore, the effectiveness of trade unions is also related to and modified by the product market structure. A monopoly is not only easy to organize but also monopolists acquiesce in union demands on account of a permissive product market environment.

Apparently there seems to be a consensus among the majority of researchers on the subject that these non-competitive elements, e.g. product market monopoly and trade unions, lead to a level of wages higher than would prevail under competitive market conditions. Changes in the level of wages cannot, however, be attributed to these factors, because "sooner or later the opportunity for a static wage advantage will be fully exploited" [1]. Any association between imperfections in the product market or the factor market and relative wage changes will imply that static non-competitive advantage was not fully exploited in the recent past. In the short run, these non-competitive elements will not change, hence relative wage changes are explained by an excess demand for labour.

However, such an analytical framework cannot fully explain interindustrial wage differentials in a country like Pakistan partly because of the rural manpower reservoir, which weakens considerably the excess demand for labour hypothesis. Besides, the concentration in the product market may be difficult to specify empirically in the presence of excessively high tariff protection and import licensing. Neglect of foreign trade is another limitation of the above-mentioned framework because industries involved in export trade have to face international competition, which has a definite bearing on their wage policies.

This paper presents a cross-sectional analysis of the production workers' wages for 1970-1971 and wage changes between 1969-1970 and 1970-1971. The objective of the study is to determine the relative effects of various factors like workers' characteristics (skill), workers' organizations and industrial characteristics on wages. We shall also carry out a pooled cross-section and timeseries analysis of average industrial wage involving fifteen industrial categories at the two-digit level classification for nine years. Non-availability of relevant time-series data on variables like trade unions, skill, and product market concentration perforce reduced this latter analysis to the investigation of an association between industrial wages and productivity, share of wage in total pro. duction costs, and employment. Despite being limited in its scope, it provides a check on the relevance of the excess demand for labour hypothesis which is discussed at length in this paper.

The analysis in the paper has been organized in three sections. In the first section, we discuss the possible determinants of inter-industry wage differentials, while the empirical results are discussed in the second section. Finally, policy implications, conclusions and limitations of the study are presented.

\section{DETERMINANTS OF INTER-INDUSTRY WAGE DIFFERENTIALS}

An earlier study focused on the analysis of earnings of production workers in the manufacturing industries for the years 1964-1965 and 1969-1970 [3]. It was found that the quality of workers (skill level), capital intensity, degree of unionization and the share of foreign firms in an industrial category made a significant impact on the level of wages of production workers. The first two variables, the skill index and capital intensity, turned out to be significant variables explaining the level of wages for both the years, while the trade union variable was significant only for the year 1964-1965 and the share of foreign firms in 1969-1970. In this paper we extend the earlier study to the year of 1970-1971. In addition, the present study improves on the earlier one by including four new variables representing product market concentration, foreign trade, rate of profit and tariff protection. However, before presenting the results of this exercise, it would be useful to discuss the possible determinants of inter-industry wage differentials.

\section{Skill Index}

The quality of workers (skill level) should normally have a positive effect on their earnings. Information on skill level or quality of work force is not available. In this paper we have used a skill index to simulate the quality factor, the index being defined as the fraction of production workers which is classed as skilled. This procedure is not entirely satisfactory because we use the Indian skill index for Pakistan with the implicit assumption that skill intensities are similar in the manufacturing sectors of both the countries.

\section{Capital Intensity}

A positive association between capital intensity and industrial wage is implicit in all production functions. The book value of fixed assets divided by employment has been used in the study to denote capital intensity of an industry. However, association between capital intensity and industrial wage is not so easy to interpret. It may be a reflection of monopoly power in the product market, the degree of foreign firms' participation and the profitability of an industry. Also a systematic relationship between capital intensity and the skill index can not be ruled out.

\section{Foreign Ownership}

Foreign firms, due to various reasons, often pursue a high wage policy, out of line with the labour market conditions of a developing country. This 
policy can however be explained in terms of the eagerness of the foreign firms to avoid confrontation with the government and labour unions of the host country. In this paper the proportion of foreign controlled firms in an industry has been used as a proxy for the foreign ownership. For the purposes of this study a firm is deemed to be foreign controlled if foreigners own thirty percent or more of the equity capital. It must be mentioned that a proper test of the presumed relationship between wage level and foreign ownership requires interfirm comparisons within an industry. The lack of relevant data precluded such an undertaking, however.

\section{Profit Rates}

Trade unions are in a better bargaining position in a regime of high industrial profits. Similarly, certain fringe benefits paid to the workers, such as bonus, are customarily tied to the profits of the firms. Thus a positive association between industrial profit rate and wage level is expected $a$ priori. The ratio of non-wage value added to the book value of fixed assets as reported in the Census of Manufacturing Industries for the year 1970-1971, has been used as a proxy of profit rates. The interpretation of the relationship between profit rate and wage level is problemetic. To the extent that higher profits are due to entry barriers or tariff protection, the profit rate will reflect both product market power and import licensing.

\section{Trade Unions}

Trade unions influence the wage level by strengthening the bargaining power of the workers. Their effect on wages of the workers may be enhanced in the presence of product market concentration and high profitability. Data on the trade union membership by industrial category are available only for 1964-1965 which is used in this paper. The effect of unionism with varying degrees of product market monopoly, rate of profit and capital intensity has been assessed by incorporating interactive variables.

\section{Concentration}

Product market concentration has a bearing on inter-industrial wage differential. The reasons why large firms pay wages higher than competitive firms have already been discussed. The conventional proxy of product market concentration, i.e. the four firm concentration ratio is used in this paper. In the case of Pakistan this ratio may not be a very reliable indicator of firm's market behaviour. ${ }^{1}$

${ }^{1} \mathrm{An}$ open collusion among firms is hardly forbidden. Firms in less concentrated industries can coordinate for price setting. Price stability considerations often led the government to encourage these practices. The creation of new capacity or entry of the firm is subject to
government' licensing, which may be unrelated to the profits of the existing firms. Price competition through an increased volume of production is effectiveiy blocked because intermediate inputs, spare parts and capital equipments are subject to severe import licensing. Therefore, even in an otherwise competitive industry one may expect output levels corresponding to a monopolistic market.

\section{Tariff Protection}

Imports at different rates of import duty are allowed to supplement the domestic production. The protection extended to domestic producer presumably leads to higher profits, which may be shared by workers. The rate of tariff protection for the year 1970-1971 is used to determine its effect on industrial wages. To the extent, however, imports are allowed under licence the connection between tariff protection and product market power of a domestic producer is weakened. Had there been no licensing of imports the import duty and transport cost would have constituted a limit to which domestic producer could raise prices over and above the competitive prices in international markets. Imports being under licence afford a scarcity mark-up of varying degrees which may be unrelated to rate of tariff protection.

\section{Export Orientation}

Foreign-trade characteristics of different industries may also influence relative wages. Industries engaged in exports are under competitive pressure, hence they are expected to pay lower wage than those which cater to the sheltered domestic market. The value of exports as a fraction of the output of an industrial category is used to determine its effect on industrial wages.

\section{EMPIRICAL RESULTS}

The empirical estimation of the relationship between average annual earnings of production workers for the year 1970-1971 and the aforementioned factors is discussed in sub-section (a). In the sub-section (b) a similar exercise is conducted to explain the proportionate changes in the average annual earnings of the production workers between the year 1969-1970 and 1970-1971. This is followed by sub-section (c) where we discuss the result of pooled cross section time series for the period $1959-1960$ to $1970-1971$.

\section{(a) A Cross Section Study of Wage Differentials for 1970-1971}

The average annual earnings (wages) of production workers for the year 1970-1971 for 17 manufacturing industries (at the two digit level classification) are regressed on various independent variables. The results of this exercise have been presented in Table 1. As can be seen only half or less than half of the variance in relative wages can be explained in this way. All the three independent variables (in equation 1) skill index, foreign participation, and export orientation - turn out to be significant. An addition of the trade union variable (in equation 2) does not add to the explained variance. However, it injects a multicollinearity which renders the export orientation variable insignificant and affects adversely the significance level of the skill index. An examination of other equations reveals that addition of variables like capital intensity, concentration and tariff protection hardly improves the fit. 
The inter-relations between different variables and the associated multicollinearity lead to inconsistent significance levels of many variables in different equations. Excepting for the skill index and foreign participation, which retained the statistical significance in most of the equations, other regressors failed to qualify the conventional significance level. None of the variables, however, has an unexpected sign.

The fact that, labour-force quality or the skill index, is significant, it reflects the importance of the market forces in wage determination. As far as foreign participation, the other significant variable in the equation system, is concerned, it is hard to classify it as a market or a non-market variable. It is a distortion as well as inconsistent with the notion of profit maximization 2 if higher wage level of the foreign firms is either due to their wise posture to avoid friction with the worker and host government and/or represents adoption of their home country wage rates.

The variable representing product market power-the concentration ratio-did not emerge as significant in the presence of factors like skill index. Concentration ratio is, however, marginally significant (at 10 percent level) where trade unions, and interactive variable reflecting the combined effect of union power and concentration are the other two explanatory variables. The result, however, fails to support the monopoly wage hypothesis, because the coefficient of concentration ratio is of lower size than that of the multiplicative variable representing the inter-active effect of both the trade union and concentration. This is not unexpected given that fact that concentration ratio is a poor proxy of the market behaviour of the firm. ${ }^{3}$

The trade union variable does not qualify the conventional significance level in the presence of other regressors like skill index, foreign participation, and export orientation. Since the industries which are skill-intensive and dominated by foreign firms tend to be highiy unionized, the statistical insignificance of trade unions - a product of multicollinearity-hardly constitutes a proof that unions have no effect on wages. Simple correlation between unionization and wages is, however, significant. The marginal effect of union power given the concentration or capital intensity or profitability of industries is positive though declines when the other related variable increases. A perusal of these equations suggests that the trade unions exert an upward pressure on

${ }^{2}$ The conjecture that foreign firms, by paying higher than normal wages, get superior quality workers is difficult to establish. The evidence provided by Sherwani [9] and Khilji [6] suggests that foreign firms and industries dominated by foreign firms earn a lower rate of profit than the domestic firms. Any claims regarding the association between higher Wages of foreign firms and superior quality workers thus may be unfounded. Besides the goodwill and industrial relation considerations, it is possible that foreign firms pay higher wages on account of the regulations governing profit repatriation. Part of the profits $(50 \%$ or so) is legally required to be reinvested in the country which appears a disincentive for profit maximization if the available venues for additional investment are either less promising or lead to an involvement with to share their profits with workers as an earnest of their desire to gain the gcodwill.

${ }^{3}$ This result is subject to an additional qualification. Introduction of interactive variable, following Lewis [7], as an additive one introduces serious multicollinearity.

\begin{tabular}{|c|c|c|c|c|c|}
\hline Intercept & Skill Index & $\begin{array}{l}\text { ve } \\
\text { of } \\
\text { ion } \\
\text { ital } \\
\text { y }\end{array}$ & $\begin{array}{l}\text { Interactive } \\
\text { variable of } \\
\text { trade union } \\
\text { and profit } \\
\quad \text { rate }\end{array}$ & $\mathrm{R}^{2}$ & F \\
\hline $\begin{array}{c}1.54 \\
(5.13)^{*}\end{array}$ & $\begin{array}{c}1.63 \\
(2.38) \dagger\end{array}$ & & & 0.49 & $4.24 \dagger$ \\
\hline $\begin{array}{l}1.54 \\
(4.96)^{*}\end{array}$ & $\begin{array}{l}1.46 \\
(1.85) \dagger\end{array}$ & & & 0.50 & $3.21 \uparrow$ \\
\hline $\begin{array}{l}1.49 \\
(3.98)^{\star}\end{array}$ & $\begin{array}{l}1.57 \\
(1.78) \S\end{array}$ & & & 0.50 & 2.23 \\
\hline $\begin{array}{c}1.38 \\
(3.09)^{*}\end{array}$ & $\begin{array}{l}1.60 \\
(1.84) \dagger\end{array}$ & & & 0.50 & 2.26 \\
\hline $\begin{array}{l}1.64 \\
(5.26)^{*}\end{array}$ & & & & 0.33 & 2.25 \\
\hline $\begin{array}{c}2.05 \\
(10.28)^{*}\end{array}$ & & & & 0.17 & 2.92 \\
\hline $\begin{array}{l}1.29 \\
(2.81)^{*}\end{array}$ & $\begin{array}{c}0.96 \\
(1.08)\end{array}$ & 1) $\dagger$ & & 0.37 & 2.92 \\
\hline $\begin{array}{l}1.44 \\
(3.35)^{*}\end{array}$ & & & $\begin{array}{l}-1.55 \\
(-1.86) \dagger\end{array}$ & 0.34 & 2.25 \\
\hline
\end{tabular}

Note: Data used in the $\mathrm{Re}$ - Significant at $1 \%$ Significant at $5 \%$

8 Significant at $10 \%$
t-values are reported 
Table 1

Determinants of Inter-industry Wage Differentials of Production Workers, 1970-1971

\begin{tabular}{|c|c|c|c|c|c|c|c|c|c|c|c|c|c|}
\hline \multirow[b]{2}{*}{ Intercept } & \multirow[b]{2}{*}{ Skill Index } & \multicolumn{10}{|c|}{ INDEPENDENT VARIABLES } & \multirow[b]{2}{*}{$\mathrm{R}^{2}$} & \multirow[b]{2}{*}{$\mathbf{F}$} \\
\hline & & $\begin{array}{l}\text { Capital } \\
\text { Intensity }\end{array}$ & $\begin{array}{l}\text { Trade } \\
\text { Union } \\
\text { Member- } \\
\text { ship }\end{array}$ & $\begin{array}{l}\text { Foreign } \\
\text { Participa- } \\
\text { tion }\end{array}$ & $\begin{array}{l}\text { Concentra- } \\
\text { tion Ratio }\end{array}$ & $\begin{array}{c}\text { Tariff } \\
\text { Protection }\end{array}$ & $\begin{array}{c}\text { Export } \\
\text { Orientation }\end{array}$ & Profit Rate & $\begin{array}{l}\text { Interactive } \\
\text { variable of } \\
\text { trade union } \\
\text { concentra- } \\
\text { tion. }\end{array}$ & $\begin{array}{l}\text { Interactive } \\
\text { variable of } \\
\text { trade union } \\
\text { and capital } \\
\text { intensity }\end{array}$ & $\begin{array}{l}\text { Interactive } \\
\text { variable of } \\
\text { trade union } \\
\text { and profit } \\
\quad \text { rate }\end{array}$ & & \\
\hline $\begin{array}{l}1.54 \\
(5.13) *\end{array}$ & $\begin{array}{l}1.63 \\
(2.38) \dagger\end{array}$ & & & $\begin{array}{l}2.28 \\
(2.75) *\end{array}$ & & & $\begin{array}{l}-1.26 \\
(-1.41) \S\end{array}$ & & & & & 0.49 & $4.24 \uparrow$ \\
\hline $\begin{array}{l}1.54 \\
(4.96)^{*}\end{array}$ & $\begin{array}{l}1.46 \\
(1.85) \dagger\end{array}$ & & $\begin{array}{c}0.29 \\
(0.36)\end{array}$ & $\begin{array}{l}2.17 \\
(2.37) \dagger\end{array}$ & & & $\begin{array}{l}-1.19 \\
(-1.27)\end{array}$ & & & & & 0.50 & $3.21 \uparrow$ \\
\hline $\begin{array}{l}1.49 \\
(3.98) *\end{array}$ & $\begin{array}{l}1.57 \\
(1.78) \S\end{array}$ & $(0.27)$ & $\begin{array}{c}0.14 \\
(0.14)\end{array}$ & $\begin{array}{l}2.15 \\
(2.25) \dagger\end{array}$ & & & $\begin{array}{l}-1.14 \\
(-1.14)\end{array}$ & & & & & 0.50 & 2.23 \\
\hline $\begin{array}{l}1.38 \\
(3.09)^{*}\end{array}$ & $\begin{array}{l}1.60 \\
(1.84) \dagger\end{array}$ & & & $\begin{array}{l}2.19 \\
(2.18) \dagger\end{array}$ & $\begin{array}{c}0.16 \\
(0.25)\end{array}$ & $\begin{array}{c}0.15 \\
(0.37)\end{array}$ & $\begin{array}{l}-1.00 \\
(-0.82)\end{array}$ & & & & & 0.50 & 2.26 \\
\hline $\begin{array}{l}1.64 \\
(5.26)^{*}\end{array}$ & & & $\begin{array}{l}3.08 \\
(2.30) \dagger\end{array}$ & & $\begin{array}{c}0.88 \\
(1.68) \S\end{array}$ & & & & $\begin{array}{l}-3.06 \\
(-1.70) \S\end{array}$ & & & 0.33 & 2.25 \\
\hline $\begin{array}{c}2.05 \\
(10.28) *\end{array}$ & & & $\begin{array}{l}1.39 \\
(1.70) 8\end{array}$ & & & & & & & & & 0.17 & 2.92 \\
\hline $\begin{array}{l}1.29 \\
(2.81)^{*}\end{array}$ & $\begin{array}{c}0.96 \\
(1.08)\end{array}$ & $\begin{array}{c}.031 \\
(1.77) \S\end{array}$ & $\begin{array}{l}2.69 \\
(1.81) \dagger\end{array}$ & & & & & & & $\begin{array}{l}-0.8 \\
(-1.81) \dagger\end{array}$ & & 0.37 & 2.92 \\
\hline $\begin{array}{l}1.44 \\
(3.35) *\end{array}$ & & & $\begin{array}{l}1.58 \\
(2.26) \dagger\end{array}$ & & & & & $\begin{array}{c}0.74 \\
(1.56) \S\end{array}$ & & & $\begin{array}{l}-1.55 \\
(-1.86) \dagger\end{array}$ & 0.34 & 2.25 \\
\hline
\end{tabular}

Note: Data used in the Regressions are available from the author.

* Significant at $1 \%$ level

Significant at $5 \%$ level

t-values are reported in parentheses. 
wages. Their effectiveness is relatively felt more in case of less capital intensive, less profitable, and less concentrated industries. In other words it is either unionism or its threat which leads to higher wages in capital intensive and concentrated industries.

It is harder to isolate the independent effect of trade unions on wages of the production workers in the absence of information on earnings and characteristics of individuals. Skill index at two-digit level is an imperfect proxy of individuals, qualification, age and experience. It is interesting to note, however, that skill index turns insignificant in the presence of trade unions, capital intensity and interaction terms of the latter two variables. This gives an impression that union related wage gains may not be compensated fully by adjustment in the skill level of the work force.

\section{Export Orientation}

Excepting for the first equation, export variable is not significant in any of the equations. A consistent negative association between wage level and exports as a percentage of output, however, suggests that exports are largely drawn from low-wage industries. Furthermore the relative insignificance of this relation may have been due to the aggregation bias-the two-digit level classification. For instance, wages in the cotton textile industry, a major export industry, are forty percent higher than in the "other textiles" (synthetic) group, which produce only for the domestic market but both of these are grouped together under "textiles" at two-digit classification.

Manufacturing industries, by their degree of foreign trade characteristics, are generally classified into export, import competing and non-competing industries. 4 An ordinal ranking on the basis of average wages of production worker for the year 1969-1970 shows that the bottom five industrial categories fall in the category of either export (3) or the non-competing industries (2). Only three industrial categories of the import-competing group, Tobacco, Non-metallic mineral, and Wood and Furniture, qualify for the ten low-wage industries. ${ }^{5}$

A summary of the relationship between wage level and foreign trade participation of industries is presented in Table 2. It can be seen that the mean level of the production workers' wages are 28 percent higher in the import competing than in the export industries and 15 percent higher than in the non-competing industries. Skill differentials alone can hardly explain this

${ }^{4}$ The import competing category covers those industries where import substitution is nearly completed and imports are only a minor fraction of the total domestic supplies. Noncompeting industries include industries in which imports account for substantial portions of the domestic supplies. Most of the non-competing industries belong to investment and inter-

mediate goods while import competing industries cover consumer goods. includes small Bidi manufacturers and redrying plants where the wage level is generally low. If we consider only cigarettes manufacturing, then it falls in the upper wage groups. Similarly. cement manufacturing, a high wage industry, is added with small pottery maker-at the two digit level classification - in non-metallic mineral product, thereby resulting in a lower industrial wage level. 
Table 2

Annual Wages of Production Workers in Manufacturing Industries by Foreign Trade Classification, 1969-1970

\begin{tabular}{lcc}
\hline Industrial Category & $\begin{array}{c}\text { Annual } \\
\text { Wages } \\
\text { (Rupees) }\end{array}$ & $\begin{array}{c}\text { Capital Intensity } \\
\text { (Thousand Rupees } \\
\text { per Employee) }\end{array}$ \\
\hline
\end{tabular}

Import Competing Industries

Food

Tobacco

Other Textile

Wood Work and Furniture

Drug and Pharmaceuticals

Printing and Publishing

Non-Metallic

Unweighted Average

2624

2319

1836

2090

Basic Metal

Metal Product

Non-Electrical Machinery

Transport

Instruments

Electrical Machinery

1886

6.30

20.74

6.08

12.73

7.06

272

32.32

Unweighted Average

1999

15.02

\section{Export-Oriented Industries}

\begin{tabular}{lcc} 
Cotton Textile & 1723 & 6.96 \\
Sports Good & 1507 & 2.47 \\
Footwear & 2314 & 3.42 \\
Leather & 1635 & 6.07 \\
& & \\
Unweighted Average & 1794 & 5.06 \\
\hline
\end{tabular}

Sources: 1. See [4] for column 1.

2. Census of Manufacturing Industries, 1969-1970, for Columns 2 and 3. differential in the wage level. The skill index fails to exhibit a systematic positive association with import-competing industries. Capital intensity, however, appears a discriminatory variable. High capital intensity of import-competing industries bespeaks of the importance of the pattern of industrialization. Import substitution encouraged by provision of capital at an over-valued exchange rate led to capital-labour substitution in importcompeting industries. High profits due to high capital-labour ratio and protected markets resulted in higher wages under trade union pressures or wage legislation.

(b) Changes in the Wages of Production Workers: 1969-1970 to 1970-1971

Proportionate changes in the wages of the production workers between the year 1969-1970 and 1970-1971 are analyzed in this section. Since there is no information on changes in the skill index, we had to drop this variable from the set of explanatory variables. Two variables - change in the capital intensity and employment have been added to the independent variables discussed earlier. It can be seen from Table 3 that two-thirds of the variance in the changes in the relative wages in the manufacturing sector is significantly explained by trade unions, export orientation, changes in capital intensity and employment. None of the other variables like concentration, foreign participation and tariff protection turned out to be significant in our preliminary regression exercises.

Changes in capital intensity and in employment, in fact, reflect the same phenomenon-capital-labour substitution. The negative association between employment changes and changes in capital intensity, however, injects multicollinearity with the result that both of them are rendered insignificant as jointly independent variables (in equation 3 ). In the absence of either one, the other variable qualifies under the conventional significance level.

The positive effect of profit rate on wage changes is not so difficult to explain, given the proportionality between profit and certain fringe benefits like bonus established by custom and law. In addition, the association between high profits and larger wage gains may have been due to trade union pressures.

Trade unions alone significantly explain 25 percent of the variance (see equation 4). Union power is generally associated with a higher level of wages but not with higher rate of wage changes. One reason for our result may be that the year under analysis (1970-1971) is associated with and preceded by an unprecedented level of strike activity. It is plausible to find a positive effect of union on wage changes during the years of labour unrest, since high-strike activity may reflect the unions effort to regain full non-competitive advantage.

A significant negative association between export orientation and wage changes suggests that export industries resist high wage raises besides paying lower wages than in the import-competing industries. Cost competitiveness introduced by international trade hardly allows the export industries to grant wage increases equivalent to those given in other industries. 
(c) Pooled Cross Section and Time Series analysis: $1959-1960$ to $1970-1971$

In this section we investigate the association between the average industrial wage (level and changes) and share of wages in total cost of production, employment (level and changes) and average productivity (level and changes). The employment cost (wage share) as a fraction of total cost presumably influences the managerial wage decisions. The management may resist wage raises when wages account for a large fraction of total production cost. The association between employment and wages will help in assessing the allocative role of wages in the input combination of producers. Furthermore it may provide a check on the excess demand hypothesis.

The results of a pooled cross-section and time-series regression (using Error-component Model) has been presented in Table 4. The data on fifteen industrial categories at two-digit classification are pooled for the years 1959-1960 to 1970-1971. Census data are, however, not available for the years 1960-1961, 1961-1962 and 1968-1969; hence, information for only nine years is used.

The analysis has been carried out both in terms of wage level and changes in the wage level. The estimated equations are reported below.

Table 4

Results of Pooled Cross Section and Time Series Analysis. 1959-1960 to 1970-1971

\begin{tabular}{|c|c|c|c|c|c|c|}
\hline W & - & $\begin{array}{c}1.95 \\
(7.76)\end{array}$ & $+\frac{.02 \mathrm{VA}}{(2.60)}$ & $\begin{array}{l}-0.70 \mathrm{SW} \\
(-0.67)\end{array}$ & $\begin{array}{l}-0.004 \mathrm{E} \\
(-1.52)\end{array}$ & $R^{2}=0.18$ \\
\hline$\Delta W$ & - & $\begin{array}{r}0.078 \\
(1.92)\end{array}$ & $\begin{array}{c}+.09 \Delta V A \\
(4.60)\end{array}$ & $\begin{array}{c}+0.21 \mathrm{SW} \\
(0.83)\end{array}$ & $\begin{array}{l}-0.36 \Delta E \\
(-6.49)\end{array}$ & $R^{2}=0.40$ \\
\hline
\end{tabular}

Note: $\mathrm{W}=$ Annual average earnings all employee (thousand of rupees)

$\mathrm{VA}=$ Value added per employee (thousands of rupees)

$\mathrm{SW}=$ labour costs as a fraction of value of output produced in a year.

$\mathbf{E}=$ employment (in thousands)

$\Delta W=$ Proportionate change in wages i.e. $\frac{W_{t}-W_{t-1}}{W_{t}-1}$

(t-values are reported in the parentheses).

As can be seen from the equations reported in Table 4, the explained variance is substantially higher in case of the proportionate changes than in the absolute level. One reason for this phenomenon may be due to the reporting errors which get smaller when data are transformed into proportionate changes. The estimated equations show that value added per employee bears a significantly positive association with wages. This relationship is, however, difficult to interpret, because piece rate system of wage payment is not in com- 
mon use, although certain fringe benefits do depend on the profitability of the firm. Since some of the relevant variables like the skill mix, capital intensity, and profit rates are not incorporated ${ }^{6}$ in the estimation, which are expected to be highly correlated with value added. The positive association between value added and the wages may in fact reflect the impact of these variables. $\mathrm{Be}$ sides the problem of ascertaining what is being simulated through value added, the direction of the causation in the empirical association between wage and productivity is not very clear too.

The share of labour cost (SW) in the output may reflect the combined effects of entrepreneur's willingness and ability to pay. Since total production costs (value of output) also include indirect taxes, to an unknown extent, this variable may reflect the changing rates of indirect taxes. Our results fail to confirm the expectation that employers are less resistant to wage increases where employment costs as a fraction of the total production costs is small, because the relationship between the share of wages in output and changes in wage rate is positive. An OECD study [11] found the share of wages in output to be inversely related to changes in the level of wages in four out of five Western countries. However, this relationship was considered weak as it was dominated by the association between the various market variables and changes in the earnings in particular periods.

As a Marshallian determinant of the elasticity of derived demand for labour, the importance and expected sign of variable representing the share of wages in total cost depends on the elasticity of substitution between capital and labour in production and consumption, if the former is higher than the latter, the wage share may have a negligible influence and even acquire a perverse sign. In equation 1, where it is regressed on level of wages it has the expected sign but remains insignificant. There is ample evidence to support the contention that substitution elasticities in Pakistan's manufacturing sector are high [5]. This may partly explain the insignificance of the wage share.

The inverse association between employment and wages, the result of our exercise, reflects the influence of factor's prices on input combination in the production process. Our findings, however fail to confirm the excess demand hypothesis which implies a positive relationship between wages and employment. The explanation of this phenomenon lies in the rural manpower reservoir and nature of the labour market of a developing country like Pakistan.

First of all excess demand, defined as unfilled vacancies minus unemployed may not exist, because the job availability in the manufacturing sector induces a rural to urban migration which often surpasses their requirement. Admittedly there is always shortage of certain skills. This excess demand (or shortage) of few can generate a positive association between employment and wages if they are easily transferable among firms and industries and wage relativities in the firms are tenaciously maintained. None of these conditions seem to hold.?

It is interesting to note that evidence on developed countries is not very clear too and excess demand hypothesis is not fully confirmed. An OECD study groups using data for five Western developed countries (including the U.S.A.) found that, "There is no evidence of a strong systematic relationship between changes in earnings among individual industries and variations in relative employment". Similarly, Behman [2], using U.S.A. data for 1951-1963, found the effect of new hire (a proxy for excess demand) weakened when relative factor price variables are included as explanatory variables of the wage changes and remarked that "over the period of 1961-1963 changing factor prices, the long run force underlying wage determination swamped the short run effect".

\section{POLICY IMPLICATIONS}

The findings of our paper suggest that the skill of the workers is not the only determinant of the wage level of the production workers. The trade unions wield considerable influence on the level of wage differentials. Industrial characteristics like concentration, capital intensity and profitability have an impact on wage level which is enhanced by the presence of workers organisation, the trade unions. Similarly, the degree of foreign ownership and foreign trade participation of an industry has a bearing upon the wages of production worker. Responsiveness of wage to the above mentioned various variables can best be estimated by elasticity coefficients given below:

Given the fragile data base, to be discussed later, the elasticity coefficients are to be interpreted with caution. These coefficients can hardly be used for any predictive purpose. It may be seen from Table 5, however, that wages seem to be quite sensitive to the capital intensity, trade unions and profitability of the industry. The skill index failed to emerge as the most dominant factor affecting the course of wages. It must be noted, however, that the

7t appears that during the industrialization process developing countries experience a great diversity in the technological level of different industries. Within an industry, a skilled Worker from a labour-intensive plant requires substantial training for a job on modern machine in a capital intensive plant. This specincity of jobs and skill differentials (or firm and industry These constraints on workers' mobility inter-industry as well as interfirm bear upon the allocative role of wages. To the extent that the skilled jobs are filled by inexperienced new hires (to be rained wages. rise with greater job) or by internal promotions,

Reliable evidence cannot be offered in support of the rigidity of wage relativities within
(a) firm or industries. No significant correlation has been found between the wages of different skill classes like unskilled, skilled, supervisory, clerical and administrative employees across nineteen industrial categories at the two-digit level for 1969-1970. An industry paying the highest wages to administrative employees may be paying average or below average wages to its other skill categories. This lack of sympathetic movement in wages of different skill groups implies that the rise in the wages of a few who are in short supply will not be able to push up substantially the average earnings of production workers in an industry. 
Table 5

Elasticity of Wages of Production Worker
Elasticity with respect to

Value of Elasticity

1. Skill

$0.26^{\mathrm{a}}$

2. Capital intensity

$0.42^{\mathrm{b}}$

Employment

Trade union

$-0.36^{\mathrm{c}}$

$0.26^{\mathrm{a}}$

$0.21^{2}$

Concentration

$0.09^{\mathrm{a}}$

Foreign Firms Control

$-0.04^{\mathrm{a}}$

Foreign trade participation

$0.27^{\mathrm{a}}$

Profit rate

$0.09^{\mathrm{c}}$
Indicates that the elasticity is taken from Table 1

Indicates that the elasticity is taken from Table 3 .

analysis has been conducted at fairly aggregative level, and the influence of some variables may have been under-estimated as a pronounced effect at firm level gets diluted at two-digit level classification.

Given the level of aggregation of our analysis and the fact that the unionism and collective bargaining exist only at the plant level an implication of our result is that the unionized large capital intensive firms pay wages higher than the less-capital intensive small firms. The proportionality between profitability and payment of fringe benefits (such as bonus) to workers tends to sharpen this demarcation. Inter-firm disparities in wages for the same skilled class, stemming from union militancy, capital intensity and profitability of a firm should be a cause for concern. Not only does it tantamount to price discrimination but as a source of friction within the working class and pressure on small scale producer. We do not advocate curbing union activities. In fact, the encouragement of the unionization and collective bargaining at the level of industry appears to be a step in the right direction. Similarly the laws and regulations, which prescribe a relationship between profits of the firm and payment of fringe benefit to workers, need revision.

An inverse association between wages and export participation of industry is reflective of the fact that workers employed in export industries, are paid less than their counterparts in the industries which have a protected market at their disposal. This distorted wage structure appears a by-product of the import substitution drive alongwith the associated measures of tariff protection and overvalued exchange rate. Whether this polarisation of wage along the lines of foreign trade participation of an industry adversely affects the normal pattern of comparative advantage of a country is difficult to ascertain. Since this result pertains to only a single year 1970-1971, it requires further investigation. If the inverse correlation between wage and exports is verified by the latter studies then a wage subsidy to exports industries, financed by pay roll taxes in the protected industries, seems worthy of consideration.

An inverse association between employment and wages implies that generation of job opportunities in the manufacturing sector is facilitated by restraining the wage raises. Unemployment has been a pressing problem in the late 1960's and early 1970's. Thanks to the exodus of manpower to the Middle East, the pressure has been relieved and the unemployment problem seems to have been relegated to secondary importance. With the end in construction boom in Middle Eastern countries in near future the emigrants will stage a comeback. The unemployment problem will re-emerge with added dimensions and gravity.

How to prepare the economy for the impending transition from an exporter to an employer of its own manpower necessitates the study of the broader issues like choice of industrial mix, choice of technology and pricing of capital besides the wage policy. It would be naive to suggest that let the market forces of demand and supply determine the wage level which clears the labour market. Not only is such a wage structure difficult to achieve but inconsistent with norms of equity and aspirations of working class. An income policy envisaged to distribute the sacrifices equitably among all the sections of the society may prove to be an helping hand.

\section{CONCLUSIONS}

The trade unions, foreign firms and foreign trade characteristics of an industry are important determinants of the wages of production workers. Foreign firms pay higher wages but do not grant higher wage gains. The trade unions are positively associated with higher wage levels as well as larger wage raises. Industries engaged in export being under competitive pressure, pay lower wages and resist higher wage increments.

We could not find any relationship between product market power and wages. Partly this may be due to the fact that the product market behaviour of the firms cannot be captured by the conventional proxy-four firms concentration ratio -in the presence of restrictive licensing and absence of anticollusion laws. Similarly, no significant relationship between tariff protection and wage level is yielded by our analysis.

Pooled time series and cross section statistical analysis of the industrial wages (for all employees) demonstrates the importance of factor price for input 
combination in the manufacturing sector. A significant inverse association between wage (level and changes) and employment (level and changes) is a major result of our analysis.

\section{LIMITATIONS OF THE STUDY}

The study suffers from a few drawbacks, which impair the validity of our conclusions and relevance of our policy implications. The treatment of trade unions and employment as exogenous is not very satisfactory. Inter-dependence between trade union growth and wage gains is increasingly being recognized. Similarly employment and wages are jointly determined. To an unknown extent, therefore, our estimation may be running into simultaneity problem. Our failure to improve mainly stems from the paucity of data.

Since our analysis has been conducted at two digit classification level thus we have tried to explain the relationship among averages, which mask tremendous variation. Average wages as a data to be analysed has an additional problem because no adjustment for overtime work has been made due to non availability of the data. A meaningful analysis of the inter-industrial wage differentials requires information on workers' characteristics like education, skill, age, experience, and on the job training so as to disentangle the effect of worker related characteristics from others on the wage level. Such an undertaking is precluded by lack of data, however.

Received December, 1978; final version received March, 1979

\section{REFERENCES}

1. Bruce, T. Allen. "Market Concentration and Wage Increases: U.S. Manufacturing, 1947-64," Industrial and Labour Relations Review. April 1968.

2. Behman, Sara. "Wage Changes, Institutions, and Relative Factor Price in Manufacturing." The Review of Economic and Statistics. August 1968.

3. Guisinger, S. E. and Mohammad Irfan. "Interindustrial Differentials in Wages and Earnings in Pakistan's Manufacturing Sector." The Pakistan Development Review. Vol. XIV, No. 3. Autumn 1975.

4. ___ "Trade Policies and Employment : The Case of Pakistan." 1978. (Mimeographed).

5. Kazi, Shahnaz; Zahira Saleem Khan and Seemin Anwar Khan. "Production Relationship in Pakistan's Manufacturing Industries." The Pakistan Development Review, Vol, XV, No. 4. Winter 1976.

6. Khilji, Faizullah. "Multinational Corporations and Restrictive Business Practices: The Case of Pakistan." The Pakistan Development Review. Vol. XIV, No. 4. Winter 1975.
7. Lewis, H. G. Unionism and Relative Wages in the U.S.: An Empirical Enquiry. Chicago: University of Chicago Press. 1963.

8. Organization for European Cooperation and Development. Wages and Labour Mobility. Paris. 1965.

9. Sherwani, Khalid. "Some New Evidence on Concentration and Profitability in Pakistan's Large Scale Manufacturing Industries." The Pakistan Development Review. Vol. XV, No. 3. Autumn 1976.

10. Taira, Koji. "Wage Differentials in Developing Countries." International Labour Review. April 1968.

11. Watcher, Michael L. "Cyclical Variations in the Inter-industry Wage Structure." The American Economic Review. March 1970.

12. White, Lawrence. Industrial Concentration and Economic Power in Pakistan. Princeton, N.J.: Princeton University Press. 1974 